\title{
A new dawn: Rights for women in Louisa Lawson's The Dawn
}

\author{
Ingrid Mahony \\ The Australian National University
}

\begin{abstract}
Published in Australia between 1888 and 1905, Louisa Lawson's monthly journal, The Dawn, proposed a vision of society where women enjoyed increased political and social agency. Women's suffrage was integral to such a vision, and through The Dawn Lawson was able to blend arguments for the enfranchisement of women with discussions about morality, sexual difference, family and marriage. Lawson was central to the production and success of The Dawn, with the journal being her primary public platform. Somewhat surprisingly, however, most of the existing historiography foregrounds Lawson's personal life and her relationship with her son, author and poet, Henry Lawson. Although The Dawn is frequently cited as one of Lawson's most significant achievements, its contents are generally not examined in any depth. This article seeks to explore some of the key issues pursued by the journal in its campaign for women's suffrage, considering the ways in which Lawson entangled suffrage with broader anxieties surrounding social progress and improvement. As Lawson argues, womanhood suffrage was as much about the wellbeing of society as it was about equality for women.
\end{abstract}

In 1888, Louisa Lawson imagined a radical vision for the future- a time when men and women would enjoy social and political equality. Lawson believed that securing the enfranchisement of women was of paramount importance. Her perspective was informed by her experiences of growing up in poverty, an unhappy marriage, divorce and her struggle to support her children as a single mother. ${ }^{1}$ After moving to Sydney in 1883, Lawson became involved in discussions of womanhood suffrage, which fuelled her desire to improve women's position in society. ${ }^{2}$ Lawson feared that:

1 Susan Magarey, Sue Rowley and Susan Sheridan, Debutante Nation: Feminism Contests the 1890s (Sydney: Allen \& Unwin, 1993), 55.

2 Olive Lawson, The First Voice of Australian Feminism: Excerpts from Louisa Lawson's 'The Dawn' 1889-1895 (Sydney: Simon \& Schuster, 1990), 11. 
A woman's opinions are useless to her, she may suffer unjustly, she may be wronged, but she has no power to weightily petition against man's laws, no representatives to urge her views, her only method to procure release, redress, or change, is to ceaselessly agitate with the hope that after many years the sense of justice in the majority of her rulers may be stirred and some tardy concession be granted, perhaps in time to benefit her granddaughters. ${ }^{3}$

As part of her campaign for women's suffrage, Lawson began publishing The Dawn in $1888 .{ }^{4}$ From its inception, Lawson wanted the journal to be published and produced entirely by women. While other women were involved, the journal regularly espoused its editor's perspective as many articles were written and edited by Lawson herself. The journal was Lawson's primary platform and mouthpiece throughout the 17 years of its publication. In line with her political ambitions, the journal's contents covered a range of political issues, ranging from voting to temperance. By exploring the arguments and assertions presented in The Dawn, this article considers the overarching political ideas presented in the journal and argues that through advocating for women's interests, Lawson sought to herald in a new dawn for women's rights in Australia.

Crucially, Lawson's journal did not argue for women's suffrage in isolation from other political and social issues, but rather positioned the enfranchisement of women within the context of a broader improvement of women's lives. In this respect, The Dawn was radical for the period, envisioning women's suffrage as an essential and integral part of society's advancement and intertwining it with broader social debates and anxieties surrounding morality, gender, education, temperance and marriage. ${ }^{5}$ Published monthly, and sold both individually and by subscription, the journal had readers from across Australia, New Zealand, Fiji, Europe and the United States of America. ${ }^{6}$

\footnotetext{
'Women's Suffrage', The Dawn, 1 July 1889, 14.

Susan Magarey, Passions of the First Wave Feminists (Sydney: UNSW Press, 2001), 58.

Brian Matthews, Louisa (Melbourne: McPhee Gribble Publishers, 1987), 163.

Magarey, Passions of the First Wave Feminists, 58.
} 


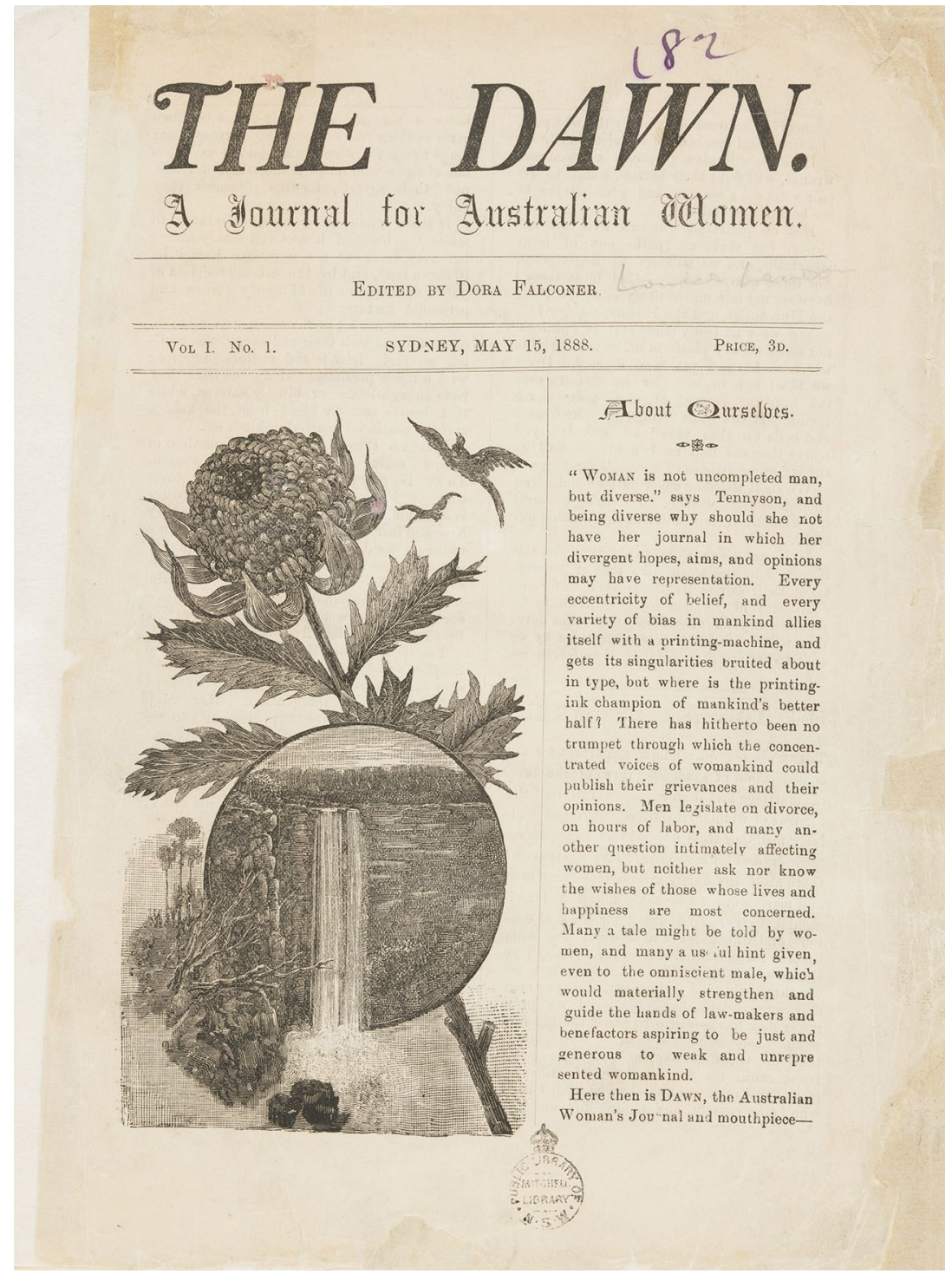

Figure 1: Front page of The Dawn, vol. 1, no. 1 (15 May 1888). Collection: State Library of New South Wales. 
Since the 1970s, the rise of women's history has seen several scholars foreground Lawson and her achievements. Susan Magarey's The Passions of the First Wave Feminists weaves Lawson's story into the context of the wider women's movement. Susanna De Vries's Great Australian Women provides a concise biography, emphasising Lawson's determination to publish The Dawn. Others have offered a more focused approach to Lawson's life. Published in 1987, Brian Matthew's Louisa tackles Lawson's life and the limitations of biography. More recently, Richard Handley's That Mad Louisa focuses on the editor's sanity, aiming to dispel accusations that she was insane-Lawson had been severely injured in a tram accident in 1902 and died, impoverished, at the Hospital for the Insane in Gladesville in 1920. ${ }^{7}$ While these publications largely focus on Lawson's life more broadly, this article will address how she used The Dawn to advocate for women's rights.

Lawson wrote most of The Dawn's editorials, with a style that has been described as 'blunt spirited, evangelising and often abrasive. ${ }^{8}$ While many historians acknowledge the role Lawson and The Dawn played in advocating for women's suffrage, they are less critical about how her concern with gender relations, marriage, temperance and employment contributed to the journal's vision of women's rights. As I argue here, by examining the editorials in several issues of The Dawn-generally the longest piece in the journal, similar to the opinion and editorial sections of other contemporary journals and magazines-it becomes clear that The Dawn actually presents a utopian vision of the political role that women might play. In Louisa, Matthews proposes that Lawson's true radicalism was that she had a vision of women's role in a new world order.' The Dawn allowed Lawson to explore the dynamics and practicalities of such a world-one where men and women were equal. A woman of this new society would have the right to vote, divorce, own land, have custody of children and to enjoy economic independence. ${ }^{10}$ She would also always put her home first.

7 Richard Handley, That Mad Louisa (Melbourne: JoJo Publishing, 2011).

8 Sharyn Pearce, 'From Bush Battler to City Editor: Louisa Lawson and the Dawn', Journal of Australian Studies 21 (1997), 13: doi.org/10.1080/14443059709387332.

9 Matthews, Louisa, 178.

10 Matthews, Louisa, 178. 
Despite Lawson's emphasis on the domestic, the image of a 'new woman' was perhaps the most radical element of The Dawn. Such a woman would occupy a leading position in a society that had been reformed by women's morality. ${ }^{11}$ The Dawn promoted women's moral influence on men, as well as the need for women's voices to be heard:

There has hitherto been no trumpet through which the concentrated voices of womankind could publish their grievances and their opinions. Men legislate on divorce, on hours of labor, and many another question intimately affecting women, but neither ask nor know the wishes of those whose lives and happiness are most concerned. ${ }^{12}$

Popular arguments against the enfranchisement of women posited that women did not know enough about politics to vote sensibly- that it was a danger to democracy if 'immoral' women were allowed to vote. ${ }^{13}$ Critics ignored the fact that 'immoral' men had suffrage, enjoying the same rights as 'moral' men irrespective of their morality. Contrary to the views of many, The Dawn argued that women knew as much about politics as men because the home was a site of politics itself, deeply entangled in public life.

Many objections to women's suffrage were based on the belief that men's and women's roles lay in separate spheres. The Victorian period brought increased division between work and home. ${ }^{14}$ As a result, women were seen as being confined to the domestic sphere, while the public sphere was dominated by men. ${ }^{15}$

Living in rural New South Wales with six children and a husband who was often away working, Lawson had experienced firsthand the helplessness of being confined by the domestic. ${ }^{16}$ Her experiences of rural life and marriage compelled her to fight for equality for men and women. At the first meeting of her suffrage organisation, the Dawn Club, Lawson appealed:

11 Matthews, Louisa, 176.

12 'About Ourselves', The Dawn, 15 May 1888, 1.

13 'Women's Suffrage', 12.

14 Magarey, Passions of the First Wave Feminists, 64.

15 Magarey, Passions of the First Wave Feminists, 64.

16 Susanna De Vries, The Complete Book of Great Australian Women (Sydney: Harper Collins, 2003), 21-24. 
Who ordained that men only should make the laws to which both men and women have to conform? [...] Pray why should one half of the world govern the other half? Is it just to first ensure the silence of the weaker half by depriving them of a citizen's status, and then inform them that by the laws of the stronger section this is the way they must act and this is the way the world may legally use them. ${ }^{17}$

Many women felt that an injustice was being committed against them by their exclusion from federal and state elections. Lawson identified the issues that women were especially concerned with: marriage and divorce, custody of children, age of consent, education and labour rights. ${ }^{18}$ These areas of concern - on which men were considered unqualified to provide advice-are central to how The Dawn framed and furthered their cause. Those opposed to women's suffrage argued that 'women have no need to vote because justice is always done even though they are silent'. ${ }^{19}$ Lawson's conception of femininity and masculinity was embedded in an understanding of the inherent differences between genders. Her ambition was to help erode the separation of spheres that excluded women from political participation and to elevate the political and social position of women.

Lawson firmly rejected arguments against suffrage that were based on women's lack of education or experience. The Dawn rebuked those who described women as having less knowledge of politics or commercial training than men: 'It is clear that women are at work and that they are fit to work' because of their continual labour in the home as well as their increasing presence in more public positions. ${ }^{20}$ Beyond remedying women's exclusion from voting, Lawson recognised that if she was to truly combat the presumptions underpinning anti-suffrage campaigners, women needed more than the vote; they needed agency both in the home and outside it. She was conscious of the divisiveness of opinions surrounding women's suffrage, but wanted to reconcile men and women on both sides of the debate for a future of equality:

17 'Women's Suffrage', 12.

18 John Docker, The Nervous Nineties: Australian Cultural Life in the 1890s (Oxford: Oxford University Press, 1991), 20.

19 'Women's Suffrage', 12.

20 'Women's Suffrage', 13. 
We hope to avoid sectarianism as a false and blighting thing, and recognise our helpers upon the broad basis of human being, of human kindness, of desire to think truly and to act well; we do not hope or expect to think alike, but know that there must be 'diversity in unity', and wish for the freest interchange of thought and expression and the closest criticism of both. ${ }^{21}$

As John Docker argues, The Dawn could not really be classified as separatist due to its belief in an open interchange between men and women. ${ }^{22}$ In Lawson's words, 'politics in reality covers nearly all questions which a thinking man or woman do now consider and form opinions upon'. ${ }^{23}$ Therefore, while they might manifest differently, women had just as many political interests as men. Through The Dawn, Lawson sought to broaden the conversation surrounding womanhood suffrage by giving it renewed everyday relevance, bringing politics into the home.

By positioning politics as a household issue, The Dawn was able to expand its audience. Its success was in part due to its involvement with other social movements, particularly the labour movement. Labour publications throughout the colonies published material to support the suffrage cause. Such newspapers, in conjunction with The Dawn, made the womanhood suffrage campaign more accessible to working-class families. In September 1893, the front page of the Queensland edition of The Worker featured a pro-suffrage image titled 'What We Want' (see Figure 2). While not directly associated with The Dawn per se, the image demonstrates that The Worker was concerned with similar issues. The rising sun in the background represents the dawn of a new era, one of 'prosperity' and 'equal opportunities for all' (see Figure 2). Lawson's vision of equality was not constrained to The Dawn.

21 'Women's Suffrage', 14.

22 Docker, The Nervous Nineties, 20.

23 'That Nonsensical Idea', The Dawn, 5 June 1890, 2. 


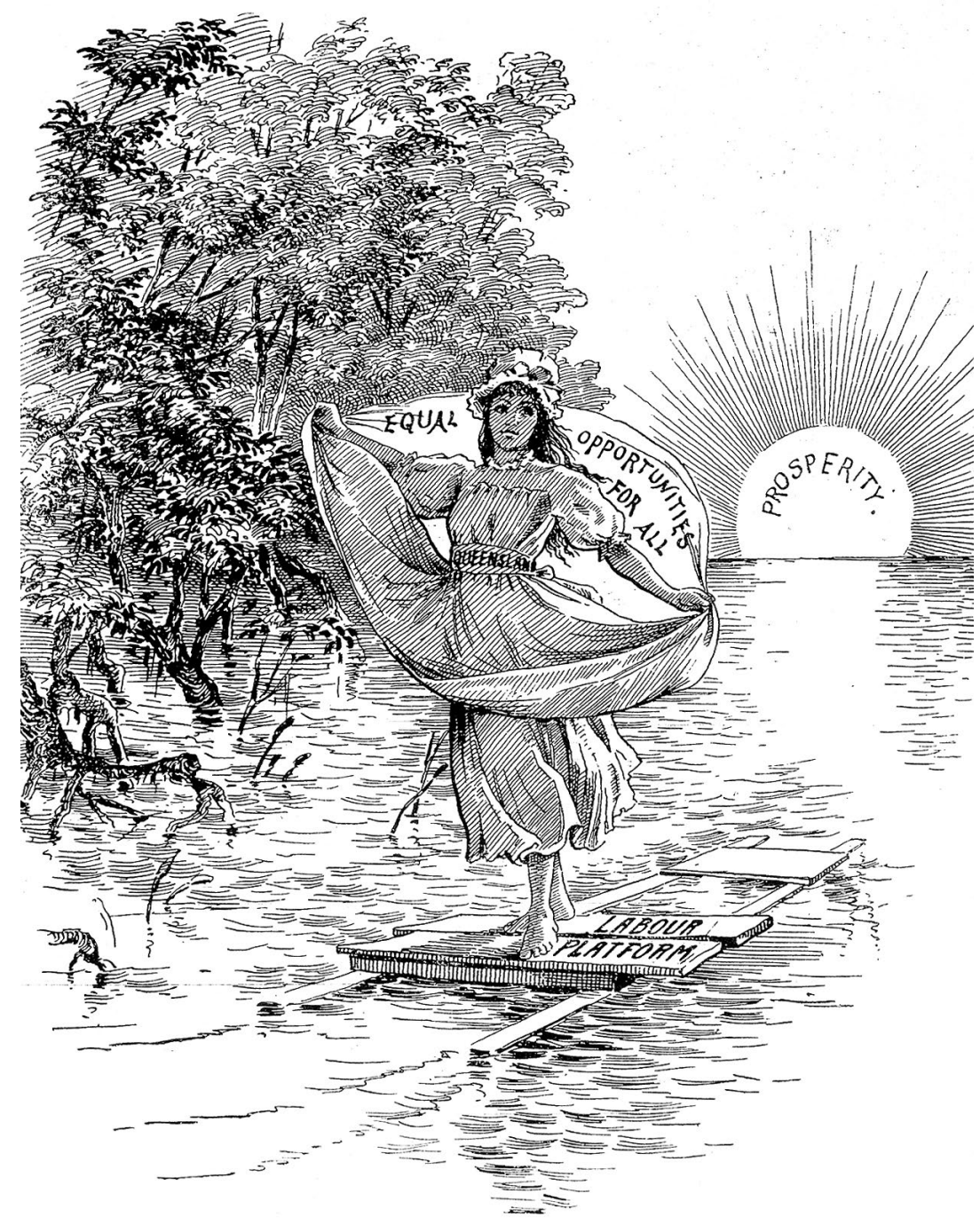

\section{WHAT WE WANT.}

Figure 2: Pro-suffrage 'What We Want' image published on the front page of The Worker, September 1893.

Collection: State Library of Queensland. 
The Dawn's position on women's role in an ideal new world order was, like arguments against the enfranchisement of women, based on assumptions of the inherent differences between the character of men and women. However, the emphasis was on women's positive traits and strengths rather than their perceived weaknesses. Central to many of The Dawn's articles was the idea that votes for women would assist in creating a more moral society because politicians-men-would be more accountable if they answered to women voters. ${ }^{24}$ In an article titled 'That Nonsensical Idea', Lawson argues that women are the 'better behaved sex' because there are more male criminals. ${ }^{25}$ While this is not the most compelling statistic, its use demonstrates how eager Lawson was to prove the essential morality of women. The journal sought to elevate the moral status of women, arguing that 'the life and work of every woman is just as essential to the good of the community as that of every man'. ${ }^{26}$ In her editorials, Lawson strategically portrays men who oppose suffrage as weak and frightened of the consequences of womanhood suffrage. As she argues in June 1890:

Probably it is because they know that with women voting the men of bad character would have little chance of future election, that makes men so fearful that women might not use it well. ${ }^{27}$

Men, according to Lawson, were frightened of the consequences of granting women direct political influence. Lawson also highlighted the 'immoral' behaviours that she saw as prevalent among the male population:

Consideration might also be well spent on the cause which has rendered prevalent among men, though absent as a rule, from women, such vices as bibulousness, gluttony, sensual appetite, and a morbid taste for gambling [...] though custom and inherited opinion have habituated us to judge the actions of men and women by different standards, the inherited squint does not justify perpetual ignorance as to the side where reform is most seriously and urgently needed. ${ }^{28}$

Lawson saw the worrying state of contemporary society as a result of excluding half the population from political processes. As Matthews suggests, The Dawn not only addressed specific political and social issues, but also sought to demonstrate that society could be perfected by

24 'Women's Suffrage', 12.

25 'That Nonsensical Idea', 2.

26 'That Nonsensical Idea', 1.

27 'That Nonsensical Idea', 2.

28 'The Man Question, or the Woman Question Re-stated', The Dawn, 2 September 1889, 6. 
following the example set by women. ${ }^{29}$ As such, Lawson believed that granting women the right to vote would encourage both men and women to better care for each other. ${ }^{30}$

The February 1891 issue of The Dawn saw its subtitle change from 'a journal for Australian women' to 'a journal for the household'. The change highlighted what had been present from the start: Lawson was not simply pitching her ideas to Australia's middle class, but to everyone in every home, including husbands and children.

The Dawn even included sections for children, although much of the advertising content was dedicated to products and services for the household, including cleaning products, clothing and medical advice. Like other feminists of the period, Lawson still regarded the household as central to a woman's life. For example, she did not necessarily seek the right for women to stand for Parliament, believing that a woman would always put the home first. ${ }^{31}$ The ideal woman of Lawson's utopian future was multi-tasking: active in political life while also caring for her family and household. One article uses Queen Victoria as an example of a woman who traverses private and public spheres. She is synchronously a good public leader, a good wife and a mother: the perfect woman. ${ }^{32}$ Here, images of domesticity are positioned as essential to feminine power.

In The Dawn's editorials, women and girls are upheld as more useful to the community because they are central to home life. Lawson describes how daughters help their mothers while sons are idle. She appears to reference her own experiences, writing of a woman who tirelessly runs a boarding house to support her family while her son plays cards and the piano. ${ }^{33}$

There are hundreds of young fellows able to work, yet invariably idle: so long as they have parents, they think it the duty of those parents to support them. There are mothers who are almost content to see their sons idle at home, so greatly do they apprehend disgrace and trouble when the boys are abroad and unwatched, and though education has, in many cases, a happily mollifying effect, the balance is against the men in all classes. A city man complained the other day that of his six sons,

29 Matthews, Louisa, 178.

30 Marilyn Lake, 'Women and Nation in Australia: The Politics of Representation', The Australian Journal of Politics and History 43, no. 1 (1997), 41: doi.org/10.1111/j.1467-8497.1997.tb01377.x.

31 'That Nonsensical Idea', 3.

32 'The Man Question, or the Woman Question Re-stated', 6.

33 'The Man Question, or the Woman Question Re-stated', 6. 
he had little hope of either; another mourned the ruin of his only son, now a confirmed drunkard. Hundreds of others dare not enquire what is the evening occupation of their sons, being well aware that tippling, gaming, or compassing the ruin of some poor girl, form their customary employments. $^{34}$

While many boys sat idle, they were able to vote. At the same time, moral women and ladies who could help reform society were unable to do so. ${ }^{35}$ Intriguingly, although Lawson saw the household and family as of central importance, marriage was not necessarily a beneficial or happy arrangement for women. Thus, The Dawn consistently campaigned for women's rights within marriage. Without adequate protection under the law, women were vulnerable to the tyranny of abusive partners. For example, in articles relating to the Divorce Extension Bill of 1890, Lawson positioned herself as a staunch supporter:

There is no law to punish a man for deceiving his wife. He may do violence to the best feelings of her nature; outrage the holiest emotions of her heart, and there is none to condemn. If he defrauds his fellow man of a shilling the law will deal with him. If he robs his wife by brutal deceit of all faith in mankind, health, peace, happiness, and of her life by the slow torture of a breaking heart-what of it? All he has to do is to bury her and seek another victim in another woman who believes him. ${ }^{36}$

Here Lawson highlights the injustice of women's lack of legal protection within the home; a married woman was without legal protection from her husband: the wife was effectively punished for her husband's behaviour because she remained trapped in the marriage. ${ }^{37}$

In addition to advocating for increased rights through the Divorce Extension Bill, The Dawn encouraged women's economic independence. Work was seen as the key to preventing women from being forced into unhappy marriages. ${ }^{38}$ Economic independence for women was at the centre of the vision of a new world order. Lawson's vision is clear in the leading article of 1 August 1892:

\footnotetext{
34 'The Man Question, or the Woman Question Re-stated', 6.

35 'The Man Question, or the Woman Question Re-stated', 6.

36 'The Divorce Extension Bill, Or, The Drunkard's Wife', The Dawn, 6 March 1890, 7.

37 Marilyn Lake, Getting Equal (Sydney: Allen \& Unwin, 1999), 8.

38 Docker, The Nervous Nineties, 12.
} 
In a hundred years her economic dependence, which is one of the chief causes of trouble in our present marriage law will have given place to recognition and accordance of her proper place in the monetary and social relations of the community. ${ }^{39}$

This recognition extends beyond an acknowledgement of women's capacity to work, envisioning a 'legal union of equality' where husband and wife are entitled to equal rights within their marriage. ${ }^{40}$ Lawson believed that this equality would provide stronger, more stable and healthier marriages, which would in turn strengthen the state. She called marriage 'an institution [that] has been found necessary to the well-being of the state'. ${ }^{41}$ As John Docker argues, The Dawn maintained that the family was the foundation of the state. ${ }^{42}$ In many ways, the campaign for equal rights in marriage was part of the broader campaign for women to have their voices heard in the political sphere.

The Dawn demonstrates how various social movements were interrelated during the 1890s. For instance, the temperance movement arose from a general concern that society was degrading morally and women and children were unsafe when their husbands and fathers were drunken. ${ }^{43}$ Many women who joined temperance organisations sought to protect themselves and their families from the antisocial behaviour that often accompanied men's consumption of alcohol. ${ }^{44}$

Lawson reflects similar views in The Dawn, lamenting that idle men often become drunkards because they have nothing else to do with their time due to their domestic idleness. ${ }^{45}$ She believes that temperance would reduce the pressure on the woman to keep the household together and presents solutions to increasing societal degeneracy. In an article from August 1901, Lawson even agitates for the wide availability of fresh water in order to prevent 'our men and boys from being driven to the necessity of entering a public-house when thirsty'. ${ }^{46}$ The attention to the details of this issue, such as adequate provision of fresh water, demonstrates how

39 'Marriage Not A Failure', The Dawn, 1 August 1892, 7.

40 'Marriage Not A Failure', 7.

41 'Marriage Not A Failure', 7.

42 Docker, The Nervous Nineties, 20.

43 'Adult Suffrage', The Dawn, 1 August 1901, 7.

44 Jack Blocker, David Fahey and Ian Tyrrell, Alcohol and Temperance in Modern History (California:

ABC-CLIO, 2003), 76.

45 'The Man Question, or the Woman Question Re-stated', 6.

46 'Adult Suffrage', 7. 
Lawson was concerned with the welfare of families across all social classes and the emphasis that she placed on the family as the foundation of the state. ${ }^{47}$ Without cohesive families that provided for and cared for each other, men and women could not enjoy equality.

From the beginning of the journal's publication, Lawson argued that women needed to decide on their own opinions; she wanted her readers to have faith in their independent thoughts and judgements, firmly believing that women should speak for themselves. In an interview for the Bulletin, Lawson told the interviewer:

No, I don't run down men, but I do run down their vanity-especially when they're talking and writing about women. A man editing a ladies' paper! Or talking about a woman's question in Parliament! I don't know whether to laugh or cry: they know so little about us. We see it. ${ }^{48}$

Describing the status of the suffrage movement in 1890, Lawson wrote that 'those who have no opinions should begin to lay the foundations on which to build a sane judgement one way or another'. ${ }^{49}$ Here it is clear that Lawson saw The Dawn as integral to preparing women for enfranchisement, dispensing knowledge that would aid women in making informed decisions. This appeal continued through the 1890s and into the new century, illustrating how the suffrage question was not easily resolved after Federation. On the front page of the August 1901 edition, every woman was urged 'to seriously consider her duty with respect to the responsibilities to the franchise'. ${ }^{50}$ While there appears to be some concern that women were not united enough in the suffrage movement, Lawson characterised opponents' arguments as overused and outdated:

That we have not cried loud enough and with one voice has been the peg upon which opponents to womanhood suffrage in and out of Parliament have hung their time-worn and threadbare arguments against the granting of the parliamentary vote to women. ${ }^{51}$

The Dawn considered women responsible for supporting womanhood suffrage. Lawson's appeals to women demonstrate how she wanted women to be engaged and held accountable in the same way as men. By 1903,

47 Karen Lee, 'The Vote that Shook the Nation', The Australian Rationalist, no. 80 (June 2008), 5.

48 AG Stephens, 'A Poet's Mother: Louisa Lawson', in Colonial Voices, ed. Elizabeth Webby

(Brisbane: University of Queensland Press, 1989), 353.

49 'Suffrage', The Dawn, 5 June 1890, 3.

50 'Adult Suffrage', 7.

51 'Adult Suffrage', 7. 
The Dawn was able to write about how the enfranchisement of women had changed society. According to Lawson, the position of women in New South Wales had changed materially in 'public as well as private life' following suffrage. ${ }^{52}$

Louisa Lawson's The Dawn envisioned a new world order where men and women would enjoy equal rights. Lawson's views were radical and hopeful, for they not only advocated womanhood suffrage, but imagined the widerranging political and social elevation of women. The Dawn's 17-year print run established a wealth of literature that demonstrates how womanhood suffrage was closely interrelated with other social causes. In many respects, Lawson's vision of the role women would play in society's future heralded arguments of modern feminism. The Dawn sought to ensure that women's voices were heard in the political sphere by consistently and passionately arguing that women have as much right as men to vote. During the course of its publication, it set the foundations for a future that would welcome a new dawn of women's rights.

52 'Circumstances Alter Cases', The Dawn, 1 June 1903, 6. 
This text is taken from ANU Historical Journal II: Number 1, published 2019 by ANU Press, The Australian National University, Canberra, Australia.

doi.org/10.22459/ANUHJII.2019.09 